\title{
Globalization and it's impacts on the course of politics in South Asia
}

\begin{abstract}
It has been observed that the trends of globalization established after the World War II have had tremendous impacts on the course of world politics, economic and social structures. Under the new world order the nation state system is said to have started decaying. It has also been observed that the world system became so overburdened that it had to create space for regional arrangements. In this study an effort has been made to bring up the new trends of the subject. Also the topics of globalism and regionalism are discussed with a special reference to South Asia. A descriptive and analytical research method is applied for getting closer to the main topic. A new and fresher look has been given to the existing data to fill the gap in the research.
\end{abstract}

Volume I Issue I - 2017

Muhammad Idrees

International Islamic University Islamabad, Pakistan

Correspondence: Muhammad Idrees, International Islamic University Islamabad, Pakistan, Tel +6I 4 70786984,

Email idreessehir@gmail.com

Received: October 18, 2016| Published: April 03, 2017

Keywords: globalization, cultural stability, historical process, ideological differences, regionalism

Abbreviations: NAFTA, North American Free Trade Agreement; ASEAN, Association of Southeast Asian Nations; SAARC, South Asian Association for Regional Cooperation

\section{Introduction}

The twenty first century is an Era of greater connectivity and interdependence where no one can afford isolation in the umbrella of nationalism. State as an international person is imagined to be losing its personality to the dawn of Globalization. Globalization is a process which generates flows and connections, not simply across nation-states and national territorial boundaries but between global regions, continents and civilizations. This invites a definition of globalization as 'an historical process,' which engenders a significant shift in the spatial reach of networks and systems of social relations to transcontinental or interregional patterns of human organization, activity and the exercise of power. ${ }^{1}$

\section{Post world war II trends}

Some researchers are of the view that:

1. Globalization is a concept that acknowledges the solution of all the problems of nation-states

2. It further encourages the nation state to get together and move towards one global system.

Globalization involves economic integration the transfer of policies across borders, the transmission of knowledge, cultural stability, the reproduction and relations. It is a global process, a concept, a revolution, and establishment of the global free market. ${ }^{2}$ There is a perception that the global system which emerged in the post World War II has become so strong that today it can affect the regional and sub regional systems and trans-national social structure. Observed that in the twentieth century the global system was greatly influential on national societies and the regions of the world, in post 1945 period

${ }^{1}$ Dr. Nayef R.F. Al-Rodhan, "Definitions of Globalization: A Comprehensive Overview and a Proposed Definition." Discussion Paper 113 (Geneva: UNCTAD, March 1996), p. 7.

${ }^{2}$ Nayef, "Definitions of Globalization." 1. this influence is further strengthened and more specifically in the last twenty years ${ }^{3}$.

\section{Lack of global governance}

The lack of global governance is a serious conflict for Globalization. There is a misunderstanding regarding the global problems and regional politics. It is obvious that there is no global decision making mechanism to safeguard the interests of the weak countries. ${ }^{4}$ Regionalism is meant for the benefit of the concerned region in effect to the benefit of regional countries. Taking globalism alone could not be a remedy for the ailments of the world politics and economy. It would be undermining the importance of social and cultural values, history, language and technology and most importantly the political systems. So regionalism is regarded as a co-actor of globalization. Some researchers consider globalization as a threat to the nationstate system. They argue that today regionalism looks the only means of cooperation. They further hold that it looks able enough to deal the threats of Globalization through institutional mechanism or in a decentralized manner. It is notable that only regional arrangement looks capable to act efficiently in the governing of Globalization. ${ }^{5}$ Researchers and analysts argue that regionalism and multilateralism are tools for governing 'globalization.' A researcher comments that it is imperative for the states to respond the exhortative dictations of globalization through multilateral cooperation for preventing the loss of their role in the international arena. ${ }^{6}$

\section{Uni-polarity of the world}

Globalization refers to all those processes by which the peoples of the world are incorporated into a single world society, global society. ${ }^{7}$ The cold war period experienced 'ideological differences' during

${ }^{3}$ I. Clarck (1997) and L. Fawcett and A. Hurrell, eds. (1995).

4"Globalization and development," (Brasilia: May, 2002), accessed January 2, 2013, http://www.eclac.org/publicaciones/xml/0/10030/Globalization-intro. pdf.

${ }^{5}$ Nayef, "Definitions of Globalization." 4

${ }^{6}$ Dr. Carlos J. Moreiro Ganzález, GOVERNING GLOBALISATION: The answer of Regionalism, (Brussels, 21-24 Novermber 2006), p. 2.

${ }^{7} I$ bid, p.4. 
which the world was expressed to be 'bipolar,' the two powerful blocs were leading the world into two opposite directions. The ideological differences were represented by

1. Capitalist bloc under the leadership of U.S.A

2. Communist bloc under the sponsorship of U.S.S.R.

During this Era the world was imagined to be divided into two ideological regions. But soon after the collapse of the former U.S.S.R the world became uni-polar and there are slogans for one global system. It is assumed that, after the collapse of soviet styled communism in Eastern Europe the elites of the global north made their version of globalization public. ${ }^{8}$

\section{The Post 9/I I World Order}

The post 9/11 international order has an inclination towards the sole super power tendency. The new global order acknowledges American lead in the military, political, economic and technological spheres. Regionalism is a resilient attempt to global changes and is being practiced according to the nature and requirement of circumstances across the globe. In the recent past the world has experienced developments in international trade and foreign investment. Other contemporary developments are the revival of regional arrangements and inception of varied regional and international organizations like European Union, NAFTA, ASEAN, Andean Community, Mercosur, SADA and SAARC etc. ${ }^{9}$

\section{The question of state sovereignty}

Globalization does not guarantee peace and security across the globe in its complete sense. But it wants the global actors to do more to ensure global security paradigm. Seemingly there is a feeling of insecurity inside the particular regions as for example in the Asian region and the state sovereignty has been at stake as Pakistan. ${ }^{10}$ Pakistan has been a U.S non-NATO ally in the 'war against terror' since 9/11. The U.S involvement in Afghanistan has been threatening the peace of the Asian region in general and Pakistan's state sovereignty in particular. Globalization is also defined as "the weakening of state sovereignty and state structure. ${ }^{11}$ On the other hand regionalism presents itself as a kind of solution in the regional security scenario. Globalization makes the security status of the state more complex that is why we are to support that the state is incapable of licensing the protection of its populous and territory. ${ }^{12}$ Globalization may indeed mean the end of the nation-state if the nation-state fails to redefine itself in the new global context. ${ }^{13}$

\section{Regionalism and the world order approach}

After getting through a series of globalization definitions we are clear that the present time globalization is enduring for political

\footnotetext{
${ }^{8}$ Albrow, Martin and Elizabeth King, Globalization, Knowledge and Societ (London: Sage, 1990), 9.

${ }^{9}$ Meyer, J. W. "The World Polity and the Authority of the Nation State" in Studies of the Modern World System," ed. A. Bergesen et al. (New York: Academic Press, 1980).

${ }^{10}$ Eric Beerkens , Globalization: Definition and Perspective (composed by Beerkens, 2006), accessed December, 2012, http://www.beerkens.info/files/ globalisation.pdf.

${ }^{11}$ [Bech: 2000, 86]

${ }^{12}$ KOLODZIEJ, E. A, "Security and International Relations," (Cambridge, 2005), http://ec.europa.eu/education/jean-monnet/doc/confglobal06/ contribution-moreiro.pdf.

${ }^{13}$ [Carnoy: 2001]
}

and economic integration of the world system. ${ }^{14}$ On the other hand regionalization is an attempt towards political, economic, social, cultural and institutional integration of the regional fiber. If compared under existing conditions one would not be exaggerating that regionalism has brought Europe under EU to the glory. South East Asian nations are on the road to prosperity under the emblem of ASEAN, South Asian region is also trying to enhance cooperation and development under SAARC. After discussing globalization theory in the regional perspective it is imperative that "regionalism is a process that provides stability, flexibility and harmonization to the existing world order." It further solidifies the world order approach by providing arch to the global system. ${ }^{15}$ The proponents of this approach profess that, "Global governmental mechanism can tackle the existing world problems in a best possible way". ${ }^{16}$

A regions' capacity is measured in its power to influence beyond its region. The Asian region as a whole is becoming a vibrant player in the world economy and has achieved tremendous bargaining power in the world political field for it hosts about 60 percent of world population, supports one-third of the world economy, more than a quarter of international exports and recipient of the largest amount of world foreign direct investment. The region is vital for its share in the global economy and attractive natural and human resource. The rising China and India are speaking beyond the Asian continent. China commands changes in the East Asia and African continent while India influences the Gulf region and to some extent the Central Asia. Pakistan's influence in the region and outside is growing, particularly with reference to Afghanistan in the U.S war on terror.

\section{Impacts of globalization on south Asia}

Analyses about SAARC and ASEAN are made that they have reached the limits where the emergence of a new Asia could be laid. South Asian leadership is about to cash the dashing potential of the Asian resurgence in the global perspective. The Indian Prime Minister Singh has rightly insisted that: A dynamic Asia could well power global growth and provide new opportunities of growth for EU and North America," He added, "China's trebling and India's doubling share to world GDP in the past decades indeed needs global institutions and new global rules of the game that would facilitate the peaceful rise of new nations in Asia. ${ }^{17}$ The Indian leader has assumed prosperity, stability and closer economic integration by terming Asian economic community as an 'Arc of advantage' for large scale movement of people, capital, labour, ideas and creativity. ${ }^{18}$

The Asian Development Bank (ADB) in a recent study has argued that regional cooperation should be a high priority for Asia. It would transfer stimulus of China and India to their neighbors and create integration with promotion of commercial linkages. Former Pakistani Prime Minister, Shaukat Aziz, suggests an integrated framework for intra-regional cooperation (in Asia) in strategic areas such as energy, water, food, infrastructure connectivity, investment in human capital and economic and social transformation through structural reforms. ${ }^{19}$

\footnotetext{
${ }^{14}$ Berkens, "Globalization."

${ }^{15}$ Samuel S. Kim, The Quest for a Just World Order, (Boulder, Colorado: West view, 1984), 61.

${ }^{16}$ Richard A. Folk is a professor of International Law at Princepton University and Saul Mendlovitz is a professor of Peace and World Order Studies, smendlovitz@kinoy.rutgers.edu.

${ }^{17}$ New Delhi statement on SAARC 2015 and Asian Resurgence (ed.), P. Lama (New Delhi: Concept Information), fes@fesindia.org.

${ }^{18}$ Ibid.
}

${ }^{19}$ Ibid 


\section{Observers role}

In this direction the role of observer states is very important. Observer status of south Asian nations in ASEAN and other regional grouping can create an opportunity for SAARC to extend its cooperation with other regional organizations of Asia. The expansion of Central Asian Gateway (CAG) project to other members as for example in the case of Central Asian Regional Economic Cooperation (CAREC) which include Afghanistan as member state, the cooperation between Afghanistan and Pakistan can bridge Central Asia with South Asia. The growing interdependence among the Asian countries in different areas like economic, environmental, financial and social areas is of great impact. This cooperation is now affecting strategic and political fields which include counter-terrorism, maritime security and exchange of expertise. ASEAN and SAARC may cooperate in trade, investment and finance.

Following areas could be remarkable for inter-regional cooperation. In energy sector, Central Asia and Gulf region can play a vital role. ASEAN can play a role in maritime security and economic fields. Communication and transport development can create inter-regional connectivity. In this connection the Asian Highway roject of the Economic and Social Commission for Asia and the Pacific (ESCAP) needs to be mentioned..$^{20}$ SAARC can also benefit from the experiences as well as cooperation of the East Asian community (EAC), the East Asia Summit (EAS), Shangai Cooperation Organization (SCO) etc.

Today the world is so connected that the proceedings of regional and international organizations are observed from outside. The world regions seem as global actors. In the increasing interdependence of the world no country, group of countries or organization is in a position to achieve the goals economic development and trade expansion without cooperation from other countries. ${ }^{21}$ Foreign diplomats and delegates from different regional and international organizations attend the deliberations of different organizations as observers with a

${ }^{20}$ Ibid, 8

${ }^{21}$ Dr. Rashid Ahmad Khan, "THE ROLE OF OBSERVERS IN SAARC." IPRI

Journal IX, no.2 (summer, 2009): 1-16. view for political, economic and cultural interaction with the member states. For example, Pakistan and Iran attend the Summit meetings of Shangai Cooperation Organization (SCO) as observers with the hope to become full-pledge members of the organization. Similarly, many countries like U.S, China, Japan and organizations like EU are joining SAARC as observers. Afghanistan has become a member of the SAARC in 2007. China, Iran and Myanmar are keen to join SAARC as full-pledge members.

The presence of some major powers as observers on its platform and the desire shown by an increasing number of other states to become observers or members of SAARC shows that the Asian regional grouping is attracting greater attention of international community due its growing importance as a regional trading bloc. These observers can play a positive role in Intra and inter regional cooperation for development and trade. ${ }^{22}$

\section{Conclusion}

Globalization is the cry of the day. It is so powerful trend that it was difficult for the world entities to take shelter under the umbrella of nationalism. The only space that was provided for the nation state system was that they could revise their status by sharing their sovereignty under regional arrangements. In the new scenario regionalism was the only way out for the state system to survive. South Asia being the inner part of the globalized world did not escape the emerging trends of globalization. In the twenty first century it is more seriously required by the regional entities to work more closely and efficiently to make their active presence on the world stage.

\section{Acknowledgements}

None.

\section{Conflict of interest}

Author declares there is no conflict of interest in publishing the article.

${ }^{22}$ Ibid, 4. 